NBER WORKING PAPER SERIES

\title{
FEMALE SOCIALIZATION: \\ HOW DAUGHTERS AFFECT THEIR LEGISLATOR \\ FATHERS' VOTING ON WOMEN'S ISSUES
}

\author{
Ebonya Washington \\ Working Paper 11924 \\ http://www.nber.org/papers/w11924 \\ NATIONAL BUREAU OF ECONOMIC RESEARCH \\ 1050 Massachusetts Avenue \\ Cambridge, MA 02138 \\ January 2006
}

I thank Joseph Altonji, Carolyn Moehling, and Rohini Pande for helpful discussions as well as seminar participants at Cornell, Harvard, MIT, Stanford Institute for Theoretical Economics: Psychology and Economics 5.0 and Yale for their comments. I thank Samantha Green-Atchley for excellent research assistance. Email address: ebonya.washington@yale.edu. The views expressed herein are those of the author(s) and do not necessarily reflect the views of the National Bureau of Economic Research.

(C2006 by Ebonya Washington. All rights reserved. Short sections of text, not to exceed two paragraphs, may be quoted without explicit permission provided that full credit, including (C) notice, is given to the source. 
Female Socialization: How Daughters Affect Their Legislator Fathers' Voting on Women's Issues

Ebonya Washington

NBER Working Paper No. 11924

January 2006

JEL No. H0, J16, D72

\begin{abstract}
Economists have long concerned themselves with environmental influences, such as neighborhood, peers and family on individuals' beliefs and behaviors. However, the impact of children on parents' behavior has been little studied. Parenting daughters, psychologists have shown, increases feminist sympathies. I test the hypothesis that children, much like neighbors or peers, can influence adult behavior. I demonstrate that the propensity to vote liberally on reproductive rights is significantly increasing in a congress person's proportion of daughters. The result demonstrates not only the relevance of child to parent behavioral influence, but also the importance of personal ideology in a legislator's voting decisions as it is not explained away by voter preferences.

Ebonya Washington

Yale University

Box 8264

37 Hillhouse, Room 2

New Haven, CT 06520

and NBER

ebonya.washington@yale.edu
\end{abstract}




\section{Introduction}

By the early eighties, after nearly two terms in congress, Senator Pete W. Domenici (RNM) had made a name for himself. "He was a gray, pragmatic fiscal and social conservative who opposed abortion, gun control and same-sex marriage and supported school vouchers, tax cuts and mandatory three-strikes sentencing. He was no bleeding heart, no cause pleader." ${ }^{1}$

That is until the withdrawn, indecisive and confused behavior of his daughter Clare was diagnosed as atypical schizophrenia.

Now Domenici is Congress' leading advocate for health insurance parity for mental illness. He is not alone. Domenici built a multiparty coalition that has included five legislators, all of whose lives have been touched by mental illness. Senator Paul Wellstone's (D-MN) older brother was severely mentally ill. Senator Alan Simpson's (R-WY) niece and Senator Harry Reid's (D-NV) father committed suicide. Representative Patrick Kennedy (D-RI) has battled depression. Senator Edward Kennedy (D-MA) is Patrick's father. ${ }^{2}$

While the coalition failed in passing legislation, their union did succeed in illustrating that a legislator's family members may influence his legislative decision making. The idea that family, in particular children like Domenici's daughter Clare, can influence parental behavior seems to accord with common sense. Yet, it is a concept that has been neglected by economists. Economists have compiled a large literature on the impacts of the environmental influences of neighborhood, peers, parents and siblings on behaviors from educational attainment ${ }^{3}$ to welfare takeup (Bertrand et. al 2000) to wedding a working woman (Fernandez et. al 2004).

Yet, only recently have we begun to consider the impact that children can have on their parent's behavior. Two recent papers demonstrate that child gender can affect parental decisions surrounding marriage, divorce and custodial arrangements (Ananat and Michaels 2005 and Dahl

\footnotetext{
${ }^{1}$ Sontag, Deborah. "When Politics is Personal." The New York Times. September 15, 2002.

${ }^{2}$ Ibid.

${ }^{3}$ Recent examples are Black et. al (2003), Dahl and Lochner (2005), Hanushek et. al (2003), Hoxby (2000) Ruhm (2004) and Sacerdote (2004).
} 
and Moretti 2004). Reichman et. al. (2003) identify a link between child health and father's presence in the household.

This paper considers whether children can influence parental behavior outside of the household, in the way that we believe neighbors and peers continue to exert influence over an individual's behavior even when the individual is not in the presence of the neighbor or the peer. Psychologists have demonstrated a link between offspring gender and parental beliefs on not only parenting issues (Brody and Steelman 1985; Downey, Jackson and Powell 1994) but also on issues of political significance. Warner (1991) examines the impact of daughters on parental attitudes toward women, in Detroit and Toronto. She finds that women with girls in both countries and men with girls in Canada are significantly more likely to hold feminist views. Warner and Steel (1999) find that US fathers are significantly more likely to support pay equity, comparable worth, affirmative action in regards to gender in employment and Title IX policies if they parent only daughters.

The shift in fathers' attitudes is particularly interesting given the "gender gap" in political beliefs in this country: a larger fraction of women than men favor the Democratic Party (Edlund and Pande 2002). ${ }^{4}$ Women are slightly more likely to believe abortion should be legally available. (Forty-four percent of women and forty-two percent of men agree with that statement.) Outside of reproductive rights, we see even larger differences between the views of the sexes. Women are four percentage points more likely to favor more crime spending (61\% vs $57 \%$ ), five percentage points less likely to favor increased defense spending ( $20 \%$ vs $25 \%$ ), ten percentage points more likely to support laws protecting homosexuals from discrimination (68\% vs 58\%) and eleven

\footnotetext{
4 This gender gap has been increasing since the late 1960's. Before this time women voted more conservatively than men. (Edlund and Pande 2002).
} 
percentage points more likely to believe that there should be more government services (41\% vs $30 \%)^{5}$

I take the evidence of attitudinal shift concerning women's issues to the political arena to ask whether parenting daughters increases a congress person's propensity to vote liberally on women's issues bills. The answer is yes. Using congressional voting record scores compiled by the National Organization of Women (NOW) and the National Right to Life Committee (NRLC), I find that proportion female children is a positive and significant predictor of voting on women's issues. In fact child gender explains one half the amount of variation in voting on women's issues as own gender. By turning to the universe of votes recorded in the $105^{\text {th }}$ congress, I demonstrate that the realm of influence of daughters is most prevalent on a women's issue on which gender differences are small: reproductive rights. The concentration of the daughter effect to the reproductive rights arena is not surprising given that past research has demonstrated a link between parenting daughters and liberal beliefs on women's issues. Reproductive rights is an issue that is thought of as uniquely female; for those voting on reproductive rights the females in their lives would be particularly salient. A second reason for the pattern of the daughter effect is that reproductive rights is a moral issue. Ansolabehere et. al (2001) and Snyder and Groseclose (2000) have found that legislators are subject to less party pressure and are therefore more free to vote their own views on moral issues.

Because the context of this study is congress, this work speaks not only to the environmental effects literature, but also to the literature that seeks to understand whether the ideology of a legislator factors into legislative decision making. Personal preference or ideology has been shown to be a factor in a congressperson's voting decisions. (See for example Levitt 1996; Snyder and Groseclose 2000 and Ansolabehere et. al 2001). But what shapes ideology? Race and gender are two components. Pande (2003) exploits the reservation of village leadership

\footnotetext{
${ }^{5}$ Author's calculations using the 1992-2000 National Election Studies. T-tests show that the gender differences on views on crime, defense, protection of homosexuals and public services are significant at the $1 \%$ level. Gender differences on abortion are significant the $10 \%$ level.
} 
positions in India for members of particular tribes and castes, to demonstrate that leaders increase transfers to members of their own ethnic group. Chattopadhyay and Duflo (2004) employ an analogous design in the same country to show that women leaders invest more in water, fuel and roads (which are needs of rural women) than their male counterparts.

While the correlation between daughters and legislative voting speaks to the environmental influence of children on parents, the conditional correlation does not demonstrate the relevance of ideology for a politician's behavior. Perhaps constituents with liberal views on female issues choose legislators with more female children, believing that these individuals can better represent their interests. However, this does not appear to be the case. I demonstrate that the association between daughters and women's issue voting is not explained away by controls for constituency desires. Not only do these findings provide additional evidence that a congress person's personal ideology or identity matters in legislative voting, but they further uncover a component of that ideology: children.

This work will remain silent on how children are able to shape their parent's voting behavior. While the study is motivated by psychological research which suggests an attitudinal shift arises from parenting daughters, alternative explanations are possible. For example, parenting daughters may increase the cost of voting conservatively on reproductive rights legislation. The increase cost could stem from the embarrassment of a visibly pregnant daughter (due to lesser access to abortion) or the monetary hardship of an unwanted grandchild. ${ }^{6}$ Separating a "true" preference shift from a cost based change in voting patterns is beyond the scope of this study. And in fact, the distinction does not seem particularly meaningful given the evidence of the applicability of cognitive dissonance to the political arena, where it has been shown that the act of voting influences political beliefs (Mullainathan and Washington 2005).

\footnotetext{
${ }^{6}$ The cost story would have to be combined with some cost for inconsistency (either dissonance or lower probability of reelection) to explain the significant proportion daughter coefficient on votes which concern abortion overseas and in federal prisons.
} 
The remainder of the paper proceeds as follows. In Section II I summarize the data and methods. I present results demonstrating the impact of child gender on legislator parents' voting behavior in Section III. Section IV provides evidence on the importance of ideology in shaping a representative's voting behavior. Section V concludes.

\section{Data and Methodology}

The data source for this analysis is a cross section of representative and district characteristics from the $105^{\text {th }}$ United States Congress (1997-1998). While there are 435 representatives in total, this study focuses on the 374 who have at least one child. ${ }^{7}$ I am limited to a cross sectional analysis because of the infrequency with which representatives augment their family size. ${ }^{8}$ The mean representative is 52 years of age at the beginning of the $105^{\text {th }}$ congress. For the most part, these men and women have completed their reproductive lives before they enter Congress. Of the individuals who served in the House between 1991 and 2004, only nine percent saw some change to their number of children during the 14 year time period. ${ }^{9}$

My primary dependent variable is the legislator voting score produced by the National Organization of Women $(\mathrm{NOW})^{10}$, a liberal leaning interest group that concerns itself with issues of interest to women. The great advantage of the NOW data, available only for the $105^{\text {th }}$ congress, is the wide variety of topics with which the organization concerns itself. To create their scores, NOW chose twenty pieces of legislation that it considered critical for women. For each vote in accordance with the NOW position, the organization awarded 5 points to produce a score that ranges from 0 to 100 with a mean of 74 for Democrats and 11 for Republicans. The legislation

\footnotetext{
${ }^{7}$ Michael Pappas (D-NJ) is not included in this analysis because I was unable to obtain information on the gender of his child.

${ }^{8}$ Further, the infrequency with which there is turnover in the Representative/district yields even a synthetic panel - tracking the gender of the children of the Representative of the district over time-uninformative. ${ }^{9}$ Of the 867 people who served in the House in the time period, I have child data for 828 of them. As a result of birth, adoption or marriage (stepchildren), sixty-nine of the 828 saw an increase in their number of children. As a result of death or divorce (stepchildren), five saw a decrease. And one, Representative Deborah Pryce (R-OH) experienced child death, divorce and adoption for both an increase and a decrease to her family size in the time period.

${ }^{10}$ Available on their website www.now.org.
} 
included in the calculation encompasses a variety of issues including equality, economic security, women's safety, education, lesbian rights, health and reproductive rights. (Descriptions of the legislation included in the NOW score are found in Appendix Table 1.) By decomposing the NOW score, I can begin to determine on which issues daughters impact their legislative parents' voting decisions. However, the NOW votes reflect only a small fraction of the nearly 1200 votes recorded in congress that session. For this reason, I perform the decomposition exercise again using all votes recorded in the United States House of Representatives during the $105^{\text {th }}$ congress.

After showing that the impact of female children on legislative voting is driven primarily by reproductive rights legislation, I add a second dependent variable to the analysis to overcome two limitations of the NOW votes. Results using the voting scores composed by the National Right to Life Committee (NRLC) ${ }^{11}$ demonstrate the robustness of the basic result across interest groups' political leanings and across time, as NRLC scores have been calculated for the $105^{\text {th }}$ through $108^{\text {th }}$ congresses. The NRLC chooses ten to twenty pieces of legislation each session, scoring each legislator on the percentage of votes on which the legislator votes in accordance with the interest group's position. The average score is 27 for Democrats and 89 for Republican members of the $105^{\text {th }}$ congress. $^{12}$

Using either NOW or NRLC scores as the dependent variable, I run regressions of the form

(1) $\mathrm{Y}=\alpha+\beta_{1}$ PROPDAUGHTERS $+\beta_{2}$ FEMALE $+\beta_{3}$ RACE $+\beta_{4}$ PARTY +

$$
\begin{aligned}
& \beta_{5} \text { SERVICELENGTH }+\beta_{6}(\text { SERVICELENGTH })^{2}+\beta_{7} \text { AGE }+\beta_{8}(\text { AGE })^{2}+ \\
& \beta_{9}-\beta_{12} \text { RELIGION }+\beta_{13}(\text { CLINTONVOTE } 96)+\gamma+\phi+\varepsilon
\end{aligned}
$$

where $\mathrm{Y}$ is a legislator vote rating score. PROPDAUGHTERS is the proportion of daughters that the individual legislator parents and $\gamma$ is a set of dummies representing total number of

\footnotetext{
11 Available on their website, www.nrlc.org.

${ }^{12}$ Results are also robust to the use of scores calculated by the American Association of University Women (www.aauw.org ) as the dependent variable.
} 
children. ${ }^{13,14}$ As shown in Table 1, in the $105^{\text {th }}$ congress, the average legislator has 2.89 children, .52 of whom are female. Republicans with children, have more children (3.13) than Democrats (2.63). Republicans have a smaller proportion of daughters (.50) than their Democratic counterparts (.54). In addition, I control for various legislator characteristics that the literature suggests are influential in determining a politician's behavior. As mentioned previously, race and gender have been shown to have a causal impact on elected official's actions. In addition, legislator party, service length, age and religion ${ }^{15}$ have been shown to be correlated with voting decisions. (See for example Hibbing and Marsh 1991 and Stratmann 2000.) I include the share of the major party presidential votes cast in favor of Clinton in 1996 and a census region fixed effects $(\phi)$ as measures of the district's liberalness. (Stratmann 2000 shows that as a district's residents become increasingly liberal so too does the voting record of its representative.) Means for all variables used to estimate Equation 1 can be found in Table $1 .{ }^{16}$

A threat to this identification strategy is that child gender may not in fact be randomly determined in this sample. Congress people may select the gender of their children to accord with their gender biases. Or constituencies with gender biases may indirectly select representatives based on child gender because of this measures' correlation with other characteristics. I discuss each threat in turn.

\footnotetext{
${ }^{13}$ The names of legislators' children are published in the Congressional Directory. In cases where the names of the children were ambiguous (with regard to gender) or omitted I consulted Internet resources, phoned the member's office (if s/he were still in office) or phoned a newspaper in the member's district. ${ }^{14}$ Conditional on total number of children, the proportion of female and proportion of male children are linearly dependent. Therefore one can interpret the results as either the effect of a having a larger share of girls or of having a smaller share of boys in the family. I refer to a daughter effect throughout the paper because that feels most natural in the discussion of women's issues.

15 Party, service length and age can all be found in the Congressional Directory. Religious data come from three sources: the Congressional Directory, the Almanac of American Politics and the following website: http://www.adherents.com/adh_congress.html.

${ }^{16}$ Results are robust to the inclusion of marital status dummies. However, I do not include these controls in my basic specification for three reasons: 1) There is no theoretical foundation from the psychological literature for such an inclusion. 2) Endogeneity of the marital decision would result in a biased coefficient. (State laws seem particularly problematic as instruments when dealing with the population who creates laws.) 3) There is little variation. Of the 423 members of the $105^{\text {th }}$ congress for whom I was able to identify marital status, $90 \%$ were married.
} 
Perhaps the same congressperson, whose preferences run counter to the NOW agenda, prefers male children over female children. ${ }^{17}$ The identification assumption would be invalid if such an individual took actions that either increased the probability that any particular child were male or increased the proportion of sons amongst his children. The possibility of increasing the probability that any individual child is male is basically non-existent for this population. With a mean age of 52 in 1998, these congress people did not have access to technology for fetal sex selection at the time of the gestation of their children. And there are no natural methods of intercourse timing that have a significant impact on child sex (Wilcox et. al 1995). While adoptive and step parents may have more flexibility in choosing child gender, both types of parenting are likely to be rare in this sample. ${ }^{18}$

While there are no natural methods that will alter the probability that any one child is a boy, a couple with male preferences could follow a natural method to ensure a certain number of sons. For example, a couple could follow a stopping rule in which they continue having children until a son is born. While such a stopping rule can never alter the proportion of female children in the overall population, it will have within family consequences for the ratio of daughters to sons. As laid out in Clark (2000) parents with male preferences will have a higher proportion of sons in small families and a smaller proportion of sons in large families. For this reason I fully saturate the model in number of children.

A congress person with male preferences is more likely to take a less extreme measure. He could distance himself from his female children, mentally or even physically as suggested by recent work documenting the correlation between marital dissolution and female children (Ananat

\footnotetext{
${ }^{17}$ For instance, Dahl and Moretti (2004) find that those who view themselves as liberal are 15 percentage points more likely than self-described conservatives to report a preference for daughters over sons.

${ }^{18}$ In 1970 - the year in which the number of adoptions peaked in the United States in the second half of the twentieth century-175,000 adoptions occurred, compared to 3.7 million births. (http://statistics.adoption.com/information/adoption-statistics-numbers-trends.html and Vital Statistics of the United States, 1998, Volume I, Natality available at http://www.cdc.gov/nchs/datawh/statab/unpubd/natality/natab98.htm.) Step parenting is also likely to be rare in this population because of the low rate of divorce. Less than $4 \%$ of the sample is currently divorced. Nationwide in $2000,15 \%$ of 45 to 54 year olds were currently divorced. (http://www.census.gov/population/socdemo/hh-fam/p20-537/2000/tabA1.pdf)
} 
and Michaels 2005 and Dahl and Moretti 2004). Such behavior would merely bias my findings toward zero as a portion of the "treated" sample is not actually receiving the treatment.

More dangerous to identification, would be if the congress person with male preferences denied his female children. In other words, he could fail to list some or all of his daughters in the Congressional Directory — my most relied upon source for identifying congress people's children—which would lead to a bias toward a positive association between daughters and voting on women's issues. While this might be a concern in a telephone survey of divorced males in the American population at large, it is unlikely to be a threat in this sample. Members of congress are public figures. The Congressional Directory is a public document. The omission of a child in this document could easily be uncovered and would likely be punished by the press and then the voting public. In fact, a Google search turned up a website that "outed" divorced Republicans. About Bob Dole, the site noted that the former Senator had "divorced the mother of his child."19

Thus it seems that it is unlikely that the legislators themselves are practicing some type of child sex selection. The issue of whether the constituents are selecting representatives in a manner correlated with child gender is addressed in Appendix Table 2. The table demonstrates that of the six district demographic characteristics (presidential voting, income, race, gender, education and religion) and five state opinion measures (abortion, gender equality, crime spending, social services spending and protection of homosexuals) only one, federal crime spending, significantly predicts the proportion of female children of the district representative. The coefficient on federal crime spending is negative suggesting that those who desire more crime spending (an opinion expressed more by women than men) select Representatives with fewer female children which would only bias the analysis against finding a child gender effect on voting on women's issues. There still remains the possibility of selection on unobserved variables. However, this seems unlikely given that for selection to bias results, it would have to be the case that candidates who assume a liberal stance on reproductive rights are more likely to be elected if they have more

${ }^{19}$ www.dailykos.com/story/2004/3/24/181127/078 
daughters (or candidates with more daughters are more likely to be elected if they take a more liberal stance on reproductive rights) whereas candidates who assume a conservatives stance on reproductive rights are more likely to be elected if they more sons (or candidates with more sons are more likely to be elected if they take a more conservative stance on reproductive rights.)

Thus I assume that conditional on total number of children, child gender can be thought of as random in the sample and run models of the form of Equation 1 to identify the impact of child gender on parental voting behavior.

\section{Basic Results}

A legislator's voting record score is increasing in the proportion of female children parented. This relationship can be seen in graphical form. Figure 1 presents the mean NOW score, by party and number of female children. The top half of the figure shows the relationship for politicians with two children. (Two is the modal number of children in the sample.) To the very left of the graph are pictured all legislators with two children. Those with one daughter earn an average NOW score that is nine points higher than those with no daughters. Those with two daughters have an average score that is an additional 18 points higher than those with one. Democrats are pictured to the right of all legislators. While their NOW scores are higher than average, the basic pattern still holds. The increase for one daughter over none is four points and for two daughters over one is ten points. Republicans, with lower NOW scores than average, again show a similar pattern. The average NOW score is seven points higher for one daughter compared with those with none. The marginal increase for the second daughter is two points.

Three is the second most popular number of children for this population. The bottom half of the figure presents the analysis for legislators with three children. Once again for legislators overall and for Democrats the mean NOW score increases with each additional female child. For Republicans the pattern is not quite as clear. The mean score is greater for those with three daughters over those with one daughter over those with no daughters. However, those with two 
daughters break the trend. This group has the lowest mean NOW score amongst Republicans with three children.

The positive relationship between proportion of daughters and NOW score holds in the face of the full set of controls. Table 2 presents results from regressions of the form of Equation 1. The first column, like the top half of Figure 1, focuses on legislators with two children. For this sample, each daughter is associated with a significant six point increase in NOW score. For the sample of those with three children (column 2) each daughter is associated with a three point, but non-significant, increase in NOW score. The analysis is expanded to all legislators with children in the final two columns of the table. The coefficient of 12.84 on proportion daughters in column 3 says that on average those legislators with all female children have NOW scores that are a significant 13 points higher than those with all male children. The column 3 specification includes no controls (other than number of children) and reflects the "pure" effect of daughters on voting if one believes that child gender may also affect other legislator characteristics, in particular choice of party. In column 4 I return to examining the impact of child gender above and beyond any of those observed legislator characteristics and find that legislators with all female children have NOW scores that are a significant six points higher than those with all male children. To put that number in perspective note that female legislators, on average, have a conditional increase in their score of 11 points over male legislators. In other words, child gender has about half the impact on score of one's own gender.

Turning attention to subgroups of representatives, I demonstrate in columns 2 and 3 of Table 3 that while both male and female legislators show a significant increase in voting record score for an increase in proportion of daughters, only for male legislators (with over seven times the sample size) is the relationship significant. (In Table 3 each cell presents the coefficient on the variable Proportion Daughters from a different regression.) Due to the imprecise nature of the female children coefficient in the female representative regression, no conclusions can be drawn about the impact of female children on the voting behavior of female representatives. In the 
remainder of the paper, I will at times refer to the influence of daughters on "congressmen" instead of "congress people" for this reason.

Scores are increasing in proportion female children for both Democratic and Republican House members. (See columns 4 and 5 of Table 3.) While the point estimate is slightly larger for Democrats, the increased standard errors mean that the estimate is significant for neither party and that the party estimates are not significantly different from one another.

Moving from subgroups of legislators to subgroups of legislation, I next decompose the NOW voting record score into its twenty component votes in order to investigate on which issue we see the greatest association between female children and voting patterns. The answer, shown in Table 4, is reproductive rights and women's safety. In this table, each row refers to a different piece of legislation included in the voting record score. Legislation is grouped into seven topic areas: equality, reproductive rights, safety, economic security, education, lesbian rights and health. The dependent variable is a dummy indicating whether the legislator voted in accordance with the NOW position on this piece of legislation. The key independent variable remains the legislator's proportion of daughters. Agreement with the NOW position is significantly increasing in proportion female children on six of the twenty issues. Those six include four of the seven votes on reproductive rights. The four concern partial birth abortion, transporting teens across state lines for abortions, FDA funding to review abortion drugs and availability of contraceptives to federal workers. While all reproductive rights specifications produced positive proportion daughters coefficients, for the remaining three reproductive rights votes, the relationship was insignificant. The remaining two issues on which proportion female children was a significant predictor of agreement with the NOW position were the two opportunities to sponsor legislation (which never came to a vote) on domestic violence programs and federal prosecution of hate crimes.

To create its voting record score NOW selected only a tiny fraction of the nearly 1200 votes recorded for the $105^{\text {th }}$ congress. While it is unlikely that NOW's selection method was a 
function of the degree to which legislators with daughters voted in accordance with their position, it is possible that their method was based on a function of some other characteristic of the legislation. Snyder (1992) argues that interest groups choose a disproportionate number of close votes exaggerating the degree of extremism and bipolarity in congress. And in fact while $75 \%$ of votes chosen by NOW were close ${ }^{20}$, only $45 \%$ of all votes taken in that congress were close. ${ }^{21}$ Such selection concerns motivate an investigation of how daughters correlate with voting across vote types. To this end I have taken all House roll call votes ${ }^{22}$ for the $105^{\text {th }}$ congress, classified them by issue type according to Ansolabehere et. al (2001) and rerun the decomposition exercise with this greatly expanded sample of 873 votes. ${ }^{23}$

Moving to the expanded sample, the reproductive rights channel appears roust. The same cannot be said for the crime channel. As Table 5 demonstrates, moral and religious issues (which include abortion and contraception) show the greatest number of significant proportion daughters coefficients. ${ }^{24}$ For $50 \%$ percent of all moral and religious votes, the coefficient on the proportion daughters is significant. ${ }^{25}$ (Fifty percent is far greater than the approximately $10 \%$ we would expect by chance under a true null of no impact of daughters on legislative voting.) The 42 moral and religious issue votes include 29 on abortion (62\% significant), two on contraception (both significant), six on church and state issues (none significant), and five others ${ }^{26}$ (of which only the one on gay adoption showed a significant correlation). On the other hand, the 12 percent of crime

\footnotetext{
${ }^{20}$ Of the 16 that actually were votes as opposed to the four bills which never made it to a vote for which NOW awarded points for sponsorship.

${ }^{21}$ Lopsided (close) defined as more (less) than $65 \%$ on the winning side as in Snyder and Groseclose (2000).

${ }_{22}^{23}$ Available on Charles Stewart's web page at http://web.mit.edu/17.251/www/data_page.html.

${ }^{23} 1187$ votes were recorded across the two sessions of this congress. For 1165 of those, yes and no votes (as opposed to a simple quorum) were recorded. 1036 of the remainder showed variation within the votes. Ansolabehere et. al (2001) assigned issue types to 876 of these. I eliminated the three votes classified as civil rights due to the small sample.

${ }^{24}$ Across issues, proportion of daughters, if significantly correlated with voting behavior, correlate positively with more liberal voting as measured by the relative behavior of Democrats and Republicans.

${ }_{25}^{25}$ At the $10 \%$ level; the same pattern of results holds at a 5\% significance level.

${ }^{26}$ On gay adoption, marijuana, teens and tobacco and suicide (2).
} 
votes for which the proportion daughter coefficient is significant is hardly greater than we would expect due to chance. ${ }^{27}$

At 29 percent, votes on labor policy show the second highest frequency of significant proportion female coefficients. Executive branch regulations at 26 percent significant come in third. While labor is an issue on which men and women disagree, ${ }^{28}$ the executive branch regulations warrant explanation. The fact is that three of the six votes that produced significant proportion daughters coefficients could easily have been classified as labor regulations. Two focus on reducing paperwork for small business, education and non-profit organizations and one on issues of health, human safety and the environment. ${ }^{29}$

The conclusion of both decomposition exercises is that while there may be some association between parenting female children and voting liberally on issues on which men and women differ significantly, such as labor and crime, the relationship between daughters and voting is strongest on an issue on which the sexes do not differ greatly-reproductive rights.

Why are votes on reproductive rights particularly influenced by a legislator's proportion of female children? For two reasons, I hypothesize. First, reproductive rights is generally thought of as precisely a women's issue. Unlike lesbian rights which focus on a subset of the female population or economic security issues which focus on a group that is broader than the female population, the focus of reproductive rights is exactly the female population. It is likely when a congressperson confronts a vote on reproductive rights, he thinks that this is a vote that will impact females. For parents of daughters, the issue then takes on "increased salience" (Warner and Steel 1999).

\footnotetext{
${ }^{27}$ However, only one of the 59 crime votes concerned violence against women in particular so one cannot conclude that proportion of female children has no impact on voting on issues of violence against women. This one vote showed an insignificant proportion female coefficient.

${ }^{28}$ As shown earlier, women are more likely than men to favor the Democratic Party and increased spending on health, education and welfare.

${ }^{29}$ The other three are on the Federal Agency compliance act, disclosing information about increased federal expenditures, and Clinton's assertion of executive privilege in the Lewinsky scandal.
} 
A second reason-unique to the congressional context—-that reproductive rights voting is more greatly tied to daughters than other NOW issues is that reproductive rights is a moral issue. Ansolabehere et. al (2001) and Snyder and Groseclose (2000) find that political parties exhibit less influence on congress person's voting on moral and religious issues in this country. In Britain, Hibbing and Marsh (1987) show that partisan forces are much weaker on so called "free votes," which "frequently deal with controversial issues, such as abortion, capital punishment, homosexuality, and the like". ${ }^{30}$ More influential on these controversial decisions are legislator personal characteristics such as religion, age and education. The decomposition results suggest that the relevant characteristics extend beyond the personal, to the environmental.

IV Impact of a Politician's Identity

Because the context of this study is the United States congress the data speak not only to how children impact a parent's behavior, but also to how the attitudes of a congress person affect representation of the constituency. An open question in political economy is to what extent the identity of the representative (as opposed to the constituency views) influences political behavior. Previous research has found that politicians favor members of their own race and gender in the distribution of resources (Pande 2003 and Chattopadhyay and Duflo 2004). The findings of Section III suggest that in addition to race and gender, family, in particular child gender may also shape a politician's behavior. However, the difficulty of such an interpretation is the possibility of omitted constituency variables from Equation 1. Perhaps female children do not cause a representative to vote more in line with the NOW positions, but rather citizens who have such liberal views believe legislators with more female children better represent them. Note however that sixty percent of self-reported voters failed to identify even one of their district candidates for House of Representatives just weeks after the election. ${ }^{31}$ It seems unlikely that voters are aware of the gender composition of candidate's children. Nonetheless, there exists the potential for an

\footnotetext{
${ }^{30}$ Given party and other political pressures, the attitudinal shifts caused by raising daughters may be more widespread than the behavioral shifts measured here.

${ }^{31}$ Author's calculations using National Election Study data for the years 1992-2000.
} 
omitted explanatory variable that correlates with both legislator child gender composition and district opinion on women's issues.

Because of the cross sectional nature of the data, I provide in this section only suggestive evidence that child gender has a causal impact on voting on reproductive rights. ${ }^{32}$ In addition to Appendix Table II which showed that non constituency characteristic apart from feelings on crime spending could predict the representative's proportion of daughters, the evidence will come from expanding the model of Equation 1 to allow for covariates to control for constituency characteristics and opinions. I find that the addition of these covariates does not significantly change the coefficient on proportion daughters. This is true not only for the $105^{\text {th }}$ congressional sample combined with the NOW voting scores, but also for the $105^{\text {th }}$ to $108^{\text {th }}$ congressional samples combined with the NRLC voting scores.

Table 6 shows results using the NOW voting scores. Column 1 repeats the basic specification from Table 2 Column 4 for comparison. In Column 2 the model is amended to include controls for district income, race, gender mix and education. ${ }^{33}$ The coefficient on proportion daughters remains significant, changing slightly from 6.18 in column 1 to 5.87 in column 2. Of the district characteristics, only fraction college graduates proves to significantly predict legislator NOW score. Each percentage point increase in college graduates is associated with a significant .5 point increase in voting score.

\footnotetext{
${ }^{32}$ Unfortunately three cleaner methods of controlling for constituent views proved uninformative. The first is to exploit the panel nature of the AAUW data and control for constituent views by means of congress person fixed effects. This method suffers from two liabilities: 1) It only captures the immediate (at most two year) impact of female children on voting. 2) There is little within person variation in number of children. A second strategy is to create a "synthetic" panel which relies on congressional district rather than congress member fixed effects. Variation comes from the change in congress people over time.

Unfortunately, there is very little turnover and this method too proved uninformative. A third strategy is to move to the Senate and control for constituent characteristics using state effects. However, the correlation between daughters and Senate voting record is insignificant, both with and without the inclusion of state dummies. Further the correlation is unstable as it switches from positive to negative depending on the congress. It is not clear whether the lack of relationship between daughters and voting in the Senate is due to sample size or an underlying difference in senatorial and representative behavior.

${ }^{33}$ Census data by district are available from Lubin 1997.
} 
In column 3 I rely on more direct measures of constituency preferences. I add to the basic model variables on public opinion on the various issues included in the NOW rating score. Drawn from the National Election Study (NES), the additional variables are the fraction of the state population who believe (around the time of the election for the $105^{\text {th }}$ congress) 1) abortion should always be legal; 2) women and men are equal; 3) federal crime spending should be increased; 4) government should spend more on services ${ }^{34}$; and 5) that there should be laws to protect homosexuals from discrimination. These variables speak to the degree to which district views are in line with NOW views and whether a correlation between district views and legislator child gender composition is driving results. ${ }^{35}$ Results in column 3 suggest that this is not the case. The addition of these variables serves to slightly increase the coefficient on proportion daughters. The relationship between NOW voting score and population views on equality, crime, spending on services and discrimination against gays proves insignificant. On the other hand, as the share of the state population who feel abortion should always be legal increases, so too does legislator NOW score. This is notable because as the decomposition exercise demonstrated, the relationship between number of female children and voting on women's issues is driven largely by the reproductive rights issue. This fact suggests that if an omitted variable bias exists, the culprit variable is likely one on popular opinion on abortion rights. As column 3 shows, the addition of such a variable does not change the basic result of about a six point increase in NOW score for a $100 \%$ increase in proportion daughters. This result is robust to the inclusion of demographic and opinion variables in a single regression, as shown in the final column of the table.

Table 7 shows that the results of Table 6 are robust across years and datasets. The dependent variable in this table is the voting score computed by the NRLC, a conservative think thank that concerns itself with reproductive issues. NRLC has computed voting record scores for

\footnotetext{
34 The question mentioned in particular health and education.

35 The limitation of these variables stems from the small sample sizes used in the NES which forces me to aggregate to state, rather than district, level in order to create reasonable cell sizes. Even at this level, I can only construct measures for thirty-five states. Individual observations for the remaining fifteen are limited or non-existent.
} 
the $105^{\text {th }}$ to $108^{\text {th }}$ congresses. Each row of the table corresponds to a different congress. The first column of the table reproduces the basic result from column 4 of Table 2 substituting the NRLC for the NOW scores. Results for the $105^{\text {th }}$ congress indicate that a $100 \%$ increase in proportion daughters is associated with a significant nine point increase in NRLC score (column 1, row 1). (The dependent variable is 100-NRLC score so that a positive coefficient still indicates voting in a more liberal direction.) That the point estimate on proportion daughters using the NRLC data is larger than that derived using the NOW data is not unexpected. NRLC focuses specifically on reproductive issues, precisely those issues that seem to be driving the association between proportion daughters and NOW score.

The remaining cells in column one demonstrate the robustness of the basic result across time. For all congresses the proportion daughters coefficient is positive and economically significant at a magnitude of five or greater. ${ }^{36}$ For three of the four congresses, the coefficient is statistically significant.

In the remaining columns of the table, I investigate whether NRLC results are “explained" by constituent characteristics by comparing the proportion daughter coefficient from models that do and do not include the additional constituency characteristics from Table 6. The final column of Table 7 presents results from the expanded model. For comparison, the middle column of the table presents results of running the basic model on the sample for which there are data to run the expanded model.

There is little evidence of omitted constituency characteristics biasing the basic model. For the two congresses in which column 2 results are significantly different from zero, column 3 results are as well. For the $106^{\text {th }}$ congress, the basic model on the limited sample (column 2) is no longer significant. But the fact that the proportion daughters coefficient grows by less than .5 with the addition of the constituency characteristics suggests there is little omitted variables bias. The proportion daughter coefficient falls by a point from column 2 to column 3 for the $108^{\text {th }}$

\footnotetext{
${ }^{36}$ NRLC awards between 5 and 10 points per vote depending on the number of votes chosen per year.
} 
congressional sample which could be interpreted as evidence of constituents "capturing" the daughter effect. However, that the daughter effect is insignificant for the $108^{\text {th }}$ congress and in the light of the evidence from the previous congresses, that interpretation seems tenuous.

Thus the evidence from the cross section points to daughters as increasing their legislator fathers' propensity to vote liberally on reproductive rights issues. This daughter voting linkage does not appear to be captured by the constituency. Rather children appear to be a part of the "ideology" that determines legislative voting, in addition to constituency.

\section{Conclusion}

While the notion that a legislator's children influence his congressional voting behavior appears commonsensical, there has, to this point and to my knowledge, been no evidence to quantitatively substantiate this intuition. This paper begins to fill this hole in the literature. I find that conditional on number of children, parenting an additional female child increases a representative's propensity to vote liberally on women's issues, particularly reproductive rights. Such a voting pattern does not seem to be explained away by constituency preferences, suggesting not only does parenting daughters affect preferences, but also that personal preferences affect legislative behavior.

Consequently these results speak to two literatures. To the realm of environmental effects, such as peers and neighborhoods, this work suggests that we should add offspring effects. Not only should we consider the impact that parents have on children's attitudes and behavior, but we should consider that there may be reverse causality in the parental/child attitude relationship.

A second contribution of this work is to the literature on congressional voting. This paper not only provides a robustness check on the finding that ideology impacts legislative voting, it also serves to identify an additional component of that ideology: child gender composition. 


\section{References}

Ananat, Elizabeth and Guy Michaeld (2005). "The Effect of Marital Breakup on the Income and Poverty or Women and Children. MIT Working Paper.

Ansolabehere, Stephen, James Snyder and Charles Stewart (2001). "The Effects of Party and Preference on Congressional Roll-Call Voting." Legislative Studies Quarterly, 26, 4, 533-572.

Bertrand, Marianne, Erzo Luttmer and Sendhil Mullainathan (2000). "Network Effects and Welfare Cultures.” Quarterly Journal of Economics, 115, 3, 1019-1055.

Black, Sandra, Paul Devereuz, Kjell Salvanes (2003). "Why the Apple Doesn't Fall Far: Understanding Intergenerational Transmission of Human Capital." NBER Working Paper No 10066.

Brody, Charles and Lala Steelman (1985). "Sibling Structure and Parental Sex-Typing of Children's Household Tasks." Journal of Marriage and the Family, 47, 2, 265-273.

Chattopadhyay, Raghabendra and Esther Duflo (2004). "Women as Policy Makers: Evidence from a Randomized Experiment in India." Econometrica, 72, 5, 1405-1443.

Clark, Shelley. "Son Preference and Sex Composition of Children: Evidence from India." Demography, 37, 1, 95-108.

Congressional Directory (1991-2004). Washington, D.C. : United States Government Printing Office.

Dahl, Gordon and Enrico Moretti (2004). "The Demand for Sons: Evidence from Divorce, Fertility and Shot Gun Marriage." NBER Working Paper Number 10281.

Dahl, Gordon and Lance Lochner (2005). "The Impact of Family Income on Child Achievement." NBER Working Paper No 11279.

Downey, Douglas, Pamela Jackson and Brian Powell (1994). "Sons Versus Daughters: Sex Composition of Children and Maternal Views on Socialization." Sociological Quarterly, 35, 1, $33-50$.

Edlund and Pande (2002). "Why Have Women Become Left-Wing? The Political Gender Gap and the Decline in Marriage." Quarterly Journal of Economics, 117, 3, 917-961.

Fernandez, Raquel, Alessandra Fogli and Claudia Olivetti (2004). "Mothers and Sons: Preference Formation and Female Labor Force Dynamics." Quarterly Journal of Economics, 119, 4, 12491300.

Hanushek, Eric, John Kain, Jacob Markman and Steven Rivkin (2003). "Does Peer Ability Affect Student Achievement?” Journal of Applied Econometrics, 18, 527-544.

Hibbing, John (1991). "Contours of the Modern Congressional Career." American Political Science Review, 85, 2, 405-428. 
Hibbing, John and David Marsh (1987). “Accounting for the Voting patterns of British MP's on Free Votes.” Legislative Studies Quarterly, 12, 2, 275-297.

Hoxby, Caroline (2000). "Peer Effects in the Classroom: Learning from Gender and Race Variation.” NBER Working Paper No 7867.

Kosmin and Mayer (2001). American Religious Identification Survey. The Graduate Center of the City University of New York.

Levitt, Steven (1996). "How Do Senators Vote? Disentangling the Role of Voter Preferences, Party Affiliation and Senator Ideology." American Economic Review, 86, 3, 425-441.

Lublin, David (1997). "Congressional District Demographic and Political Data," American University, Washington, D.C.

Mullainathan, Sendhil and Ebonya Washington (2005). "Sticking with Your Vote: Cognitive Dissonance and Voting." Working Paper, June.

Pande, Rohini (2003) "Can Mandated Political Representation Increase Policy Influence for Disadvantaged Minorities? Theory and Evidence from India." American Economic Review, 93, 4, 1132-1151.

Reichman, Nancy, Hope Corman and Kelly Noonan (2003). "Effect of Child Health on Parents' Relationship Status." NBER Working Paper No 9610.

Ruhm, Christopher (2004). "Maternal Employment and Adolescent Development." NBER Working Paper No 10691.

Sacerdote, Bruce (2004). "What Happens When We Randomly Assign Children to Families? “ NBER Working Paper No 10894.

Snyder, James (1992). “Artificial Extremism in Interest Group Ratings.” Legislative Studies Quarterly, 17, 3, 319-345.

Snyder, James and Tim Groseclose (2000). "Estimating Party Influence in Congressional RollCall Voting." American Journal of Political Science, 44, 2, 193-211.

Stratmann, Thomas (2000). "Congressional Voting over Legislative Careers: Shifting Positions and Changing Constraints." American Political Science Review, 94, 3, 665-676.

Warner, Rebecca (1991). "Does the Sex of Your Child Matter? Support for Feminism among Women and Men in the United States and Canada." Journal of Marriage and the Family, 53, 4, 1051-1056.

Warner, Rebecca and Brent Steel (1999). "Child Rearing as a Mechanism for Social Change: The Relationship of Child Gender to Parents' Commitment to Gender Equity." Gender and Society, $13,4,503-517$.

Wilcox, AJ, CR Weinberg and DD Baird (1995). "Timing of sexual intercourse in relation to ovulation. Effects on the probability of conception, Survival of the Pregnancy, and Sex of the 
Baby. New England Journal of Medicine, 333, 1517-1521. 
TABLE 1: SAMPLE MEANS

\begin{tabular}{|c|c|c|c|c|}
\hline Variable & Legislators & $\begin{array}{l}\text { Legislators with } \\
\text { Children }^{1}\end{array}$ & $\begin{array}{l}\text { Democrats }^{2} \text { with } \\
\text { Children }\end{array}$ & $\begin{array}{l}\text { Republicans with } \\
\text { Children }\end{array}$ \\
\hline \multicolumn{5}{|l|}{ Independent Variables } \\
\hline \multicolumn{5}{|l|}{ Legislator's Children } \\
\hline Number of daughters & & 1.48 & 1.4 & 1.55 \\
\hline Number of children & & 2.89 & 2.63 & 3.13 \\
\hline Proportion daughters & & .52 & .54 & .5 \\
\hline \multicolumn{5}{|l|}{ Total Number of } \\
\hline Zero & .14 & & & \\
\hline One & .09 & .11 & .15 & 7 \\
\hline Two & .32 & .37 & .40 & 34 \\
\hline Three & .22 & .25 & .24 & 26 \\
\hline Four & .13 & .15 & .12 & 18 \\
\hline Five or more & .10 & .12 & .09 & 15 \\
\hline \multicolumn{5}{|l|}{ Legislator } \\
\hline \multicolumn{5}{|l|}{ Characteristics } \\
\hline White & .87 & .86 & .74 & .97 \\
\hline Female & .11 & .11 & .16 & .07 \\
\hline Mean age & 52 & 53 & 54 & 51 \\
\hline Service length (years) & 9 & 9 & 10 & 8 \\
\hline Protestant & .60 & .66 & .52 & .71 \\
\hline Catholic & .30 & .27 & .34 & .21 \\
\hline Other Christian & .04 & .04 & .01 & .07 \\
\hline Other religion & .06 & .05 & .11 & .01 \\
\hline None & .01 & .01 & .02 & 0 \\
\hline Clinton Vote in 1996 & .50 & .50 & .59 & .43 \\
\hline \multicolumn{5}{|l|}{ Dependent Variables } \\
\hline NOW score ${ }^{3}$ & 41 & 41 & 74 & 11 \\
\hline Right to Life score & 59 & 60 & 27 & 89 \\
\hline $\mathrm{N}$ & 435 & 374 & 176 & 198 \\
\hline
\end{tabular}

${ }^{\mathrm{I}}$ Michael Pappas (D-NJ) is not included in this analysis because I was unable to obtain information on the gender of his child.

${ }^{2}$ Including Representative Bernard Sanders (I-VT).

${ }^{3}$ NOW did not calculate scores for four individuals who did not complete the entire term. For this variable, $\mathrm{n}=431$ (column 1), $\mathrm{n}=371$ (column 2), $\mathrm{n}=174$ (column 3) and n=197 (column 4). 
TABLE 2: IMPACT OF FEMALE CHILDREN ON LEGISLATOR PARENT'S VOTING ON WOMEN's ISSUES

\begin{tabular}{|c|c|c|c|c|}
\hline & $\begin{array}{l}\text { Legislators with Two } \\
\text { Children }\end{array}$ & $\begin{array}{l}\text { Legislators with Three } \\
\text { Children }\end{array}$ & $\begin{array}{l}\text { All Legislators with } \\
\text { Children }\end{array}$ & $\begin{array}{l}\text { All Legislators with } \\
\text { Children }\end{array}$ \\
\hline Number of daughters & $\begin{array}{l}6.30^{* *} \\
(2.11)\end{array}$ & $\begin{array}{c}2.69 \\
(2.03)\end{array}$ & & \\
\hline Proportion daughters & & & $\begin{array}{l}12.84^{* *} \\
(5.9)\end{array}$ & $\begin{array}{c}6.18 * * \\
(2.67)\end{array}$ \\
\hline \multicolumn{5}{|l|}{ Other Legislator Characteristics } \\
\hline Female & $\begin{array}{r}9.41 * * \\
(4.23)\end{array}$ & $\begin{array}{c}15.99 * * \\
(7.44)\end{array}$ & & $\begin{array}{l}11.31 * * * \\
(2.82)\end{array}$ \\
\hline Republican & $\begin{array}{l}-52.58 * * * \\
(3.63)\end{array}$ & $\begin{array}{c}-32.64 * * \\
(4.21)\end{array}$ & & $\begin{array}{l}-45.21 * * * \\
(2.26)\end{array}$ \\
\hline $\begin{array}{l}\text { Controls for race, service length, age, religion, } \\
\text { region and Clinton vote share }\end{array}$ & & & & Yes \\
\hline Number of children fixed effects & Yes & Yes & Yes & Yes \\
\hline $\mathrm{N}$ & 138 & 93 & 371 & 371 \\
\hline
\end{tabular}

Note: $* * *, * *, *$ denote significance at the 1,5 and 10 percent levels respectively.

TABLE 3: IMPACT OF FEMALE CHILDREN ON LEGISLATOR PARENT'S VOTING ON WOMEN'S ISSUES, BY LEGISLATOR GENDER AND PARTY

(Each cell presents the coefficient on proportion daughters from a different regression.)

\begin{tabular}{lccccc}
\hline & & \multicolumn{2}{c}{ Gender } & \multicolumn{3}{c}{ Party } \\
Data Source & All Legislators & Men & Women & Democrats & Republicans \\
\hline Proportion daughters & $6.18^{* *}$ & $6.29^{* *}$ & 4.99 & 6.07 & 4.69 \\
& $(2.67)$ & $(2.8)$ & $(12.49)$ & $(3.93)$ & $(3.64)$ \\
$\mathrm{N}$ & 371 & 328 & 43 & 174 & 197 \\
\hline
\end{tabular}

Note: All specifications include legislator race, gender, party, service length (and its square) and age (and its square), number of child, religion and region dummies and percent of two party district vote in favor of Clinton. ***,*** denote significance at the 1,5 and 10 percent levels respectively.

${ }^{1}$ Including Representative Bernard Sanders (I-VT). 
TABle 4: DeCOMPOSITION OF IMPACT OF CHILD GENDER MiX ON NOW VOTING RECORD SCORE (Dependent variable equals one if the legislator voted with the NOW position)

\begin{tabular}{lrl}
\hline Bill & $\begin{array}{c}\text { Proportion } \\
\text { Daughters }\end{array}$ & $\begin{array}{c}\text { Standard } \\
\text { Error }\end{array}$ \\
\hline Equality & .03 & $(.05)$ \\
Equal Rights Amendment & .03 & $(.05)$ \\
Pay Equity & & \\
Reproductive Rights & .11 & $(.05)^{* *}$ \\
Abortion Ban & .10 & $(.05)^{* *}$ \\
Teen Access to Abortion & .07 & $(.06)$ \\
Contraceptives for Federal Employees & .07 & $(.06)$ \\
RU-486 & .13 & $(.06)^{* *}$ \\
Teen Access to Contraceptives & .09 & $(.06)$ \\
International Family Planning & .13 & $(.07)^{*}$ \\
Contraceptive Use & & \\
Women's Safety & .10 & $(.05)^{*}$ \\
Violence Against Women & .11 & $(.06)^{*}$ \\
Hate Crimes & & \\
Economic Security & -.03 & $(.06)$ \\
Affirmative Action in Federal Contracts & .07 & $(.05)$ \\
Working Families Flexibility & -.02 & $(.05)$ \\
Bankruptcy & & \\
Education & .04 & $(.05)$ \\
Private and Religious Schools & .08 & $(.06)$ \\
Affirmative Action in Higher Education & .06 & $(.04)$ \\
Tax Free Education & & \\
Lesbian Rights & .07 & $(.06)$ \\
Discrimination in Federal Employment & .04 & $(.05)$ \\
Equal Health Care Benefits & & \\
Health & -.03 & $(.04)$ \\
Patient's Rights & & \\
\hline Note: All specifications include legislator race, gender, party, service length (and its square) and age (and \\
its square), number of child, religion and region dummies and percent of two party district vote in favor of \\
Clinton. ***, **, * denote significance at the 1, 5 and 10 percent levels respectively.
\end{tabular}


TABLE 5: DAUGHTER INFLUENCE ON LEGISLATIVE VOTING BY ISSUE TYPE

\begin{tabular}{|c|c|c|}
\hline Issue & $\begin{array}{l}\text { OLS: } \\
\text { Fraction of } \\
\text { Votes with } \\
\text { Significant } \\
\text { Daughter } \\
\text { Coefficients }\end{array}$ & $\mathrm{N}$ \\
\hline $\begin{array}{l}\text { Moral, Religious Issues } \\
\text { - Abortion } \\
\text { - Church and State } \\
\text { - Contraception } \\
\text { - } \\
\text { Other }\end{array}$ & $\begin{array}{r}.5 \\
.62 \\
.00 \\
1.00 \\
.20\end{array}$ & $\begin{array}{r}42 \\
29 \\
6 \\
2 \\
5\end{array}$ \\
\hline $\begin{array}{l}\text { Social Security, Medicare } \\
\text { General Budget, Taxes, Spending } \\
\text { Executive Branch Regulations } \\
\text { Crime Policy, Civil law } \\
\text { Business Regulation } \\
\text { House Rules, Elections } \\
\text { Health, Education, Welfare } \\
\text { Labor Policy } \\
\text { Agriculture, Fishing } \\
\text { Defense, Veterans } \\
\text { Public Works, Transportation } \\
\text { Foreign Aid, Trade, Immigration } \\
\text { Energy, Environment }\end{array}$ & $\begin{array}{l}.14 \\
.14 \\
.26 \\
.12 \\
.12 \\
.08 \\
.12 \\
.29 \\
.03 \\
.14 \\
.18 \\
.12 \\
.16\end{array}$ & $\begin{array}{r}7 \\
99 \\
23 \\
59 \\
68 \\
139 \\
74 \\
31 \\
36 \\
76 \\
51 \\
137 \\
31\end{array}$ \\
\hline \multicolumn{3}{|c|}{$\begin{array}{l}\text { Note: Data on legislative voting records is available on } \\
\text { Charles Stewart's web page at } \\
\text { http://web.mit.edu/17.251/www/data_page.html. Vote issue } \\
\text { types follow Ansolabehere, Snyder and Stewart (2001) and } \\
\text { were provided by the authors. Civil rights and gun control } \\
\text { categories not used because of sample size. None of the bills } \\
\text { the authors labeled as civil rights votes showed a significant } \\
\text { coefficient on proportion daughters. The authors categorizec } \\
\text { no bills as gun control in the } 105^{\text {th }} \text { congress. Each regressior } \\
\text { includes Democratic vote share of major party vote in } 1996 \\
\text { presidential election as well as legislator race, gender, party, } \\
\text { age, age squared, service length, square of service length, } \\
\text { and religion, child number and region dummies } \\
{ }^{1} \text { At the } 10 \% \text { level. } \\
{ }^{2} \text { This subcategory is my own creation. }\end{array}$} \\
\hline
\end{tabular}


TABLE 6: IMPACT OF FEMALE CHILDREN ON LEGISLATOR PARENT'S VOTING ON WOMEN'S ISSUES (EXPANDED MODEL), NOW DATA

\begin{tabular}{|c|c|c|c|c|}
\hline & $(1)$ & $(2)$ & $(3)$ & $(4)$ \\
\hline Proportion daughters & $\begin{array}{l}6.18^{* *} \\
(2.67)\end{array}$ & $\begin{array}{l}5.87 * * \\
(2.62)\end{array}$ & $\begin{array}{l}6.53 * * \\
(2.94)\end{array}$ & $\begin{array}{l}6.01 * * \\
(2.86)\end{array}$ \\
\hline \multicolumn{5}{|l|}{ District Characteristics } \\
\hline Clinton vote share $($ mean $=.5)$ & $\begin{array}{c}84.27 * * * \\
(11.57)\end{array}$ & $\begin{array}{c}82.38 * * * \\
(19.63)\end{array}$ & $\begin{array}{c}85.91 * * * \\
(13.18)\end{array}$ & $\begin{array}{l}82.11 * * \\
(15.77)\end{array}$ \\
\hline Median income in thousands (mean=35.69) & & $\begin{array}{l}.16 \\
(.19)\end{array}$ & & $\begin{array}{l}.21 \\
(.2)\end{array}$ \\
\hline Fraction white $($ mean $=.8)$ & & $\begin{array}{l}-4.49 \\
(9.18)\end{array}$ & & $\begin{array}{l}-8.62 \\
(9.49)\end{array}$ \\
\hline Fraction female $($ mean $=.52)$ & & $\begin{array}{l}-90.17 \\
(73.86)\end{array}$ & & $\begin{array}{l}-108.5 \\
(77.65)\end{array}$ \\
\hline Fraction college graduates (mean $=.2$ ) & & $\begin{array}{c}45.67 * * \\
(19.23)\end{array}$ & & $\begin{array}{l}41.03 * * \\
(20.57)\end{array}$ \\
\hline Constituent religion variables & & $\sqrt{ }$ & & $\sqrt{ }$ \\
\hline \multicolumn{5}{|l|}{ District Opinions } \\
\hline Fraction of state population who believe ... & & & & \\
\hline Abortion should always be legal $($ mean $=.42)$ & & & $\begin{array}{r}22.38 * * \\
(10.95)\end{array}$ & $\begin{array}{c}8.54 \\
(10.91)\end{array}$ \\
\hline Women are equal to men $($ mean $=.77)$ & & & $\begin{array}{c}-8 \\
(23.56)\end{array}$ & $\begin{array}{l}-20.63 \\
(23.11)\end{array}$ \\
\hline $\begin{array}{l}\text { Federal crime spending should be increased } \\
(\text { mean }=.68)\end{array}$ & & & $\begin{array}{l}20.29 \\
(19.14)\end{array}$ & $\begin{array}{c}30.24 \\
(18.73)\end{array}$ \\
\hline Government should spend more on services & & & -9.2 & -14.83 \\
\hline (health, education) $($ mean $=.33)$ & & & $(17.23)$ & $(16.84)$ \\
\hline There should be laws to protect homosexuals & & & 3.36 & 10.17 \\
\hline from discrimination $($ mean $=.66)$ & & & $(14.22)$ & $(13.94)$ \\
\hline $\mathrm{N}$ & 371 & $369^{1}$ & $331^{2}$ & $331^{2}$ \\
\hline
\end{tabular}

Note: All specifications include legislator number of children, gender, race, party, age and its square, service length and its square and religion and child number dummies. ${ }^{* * *}$ denotes significance at the $1 \%$ level, $* *$ at $5 \%$ and $*$ at $10 \%$.

${ }^{1}$ Constituent religion data, from Kosmin and Mayer (2001), are not available for Alaska and Hawaii. ${ }^{2}$ District opinion data are not available for fifteen states. Basic model without these states produces a coefficient on number of children of 6.34 (2.91). 
TABLE 7: IMPACT OF FEMALE CHILDREN ON LEGISLATOR PARENT's VOTING ON WOMEN'S ISSUES (EXPANDED MODEL), RIGHT TO LIFE SCORES

(Each cell presents the coefficient on proportion daughters from a different regression.)

\begin{tabular}{|c|c|c|}
\hline Basic Model & Basic Model w/Expanded Sample & Expanded Model \\
\hline \multicolumn{3}{|c|}{$105^{\text {th }}$ Congress } \\
\hline $9.31 * *$ & $10.09 * *$ & $8.13 * *$ \\
\hline$(3.9)$ & $(4.27)$ & $(4.15)$ \\
\hline$[374]^{1}$ & [333] & [333] \\
\hline \multicolumn{3}{|c|}{$106^{T H}$ CONGRESS } \\
\hline$[378]$ & {$[301]$} & [301] \\
\hline \multicolumn{3}{|c|}{$\underline{107^{T H} \text { CONGRESS }}$} \\
\hline $10.28 * *$ & $10.73 * *$ & $12.1 * * *$ \\
\hline$(3.9)$ & $(4.51)$ & $(4.4)$ \\
\hline \multicolumn{3}{|c|}{$\underline{108^{T H} \text { CONGRESS }}$} \\
\hline 5.63 & 3.46 & 2.31 \\
\hline$(3.43)$ & $(3.87)$ & $(3.83)$ \\
\hline [378] & [312] & [312] \\
\hline
\end{tabular}

Note: The dependent variable is (100-NRLC) score for comparability with NOW analysis. Basic specifications include legislator number of children, gender, race, party, age and its square, service length and its square and religion, child number and region dummies. Expanded specifications include all of the covariates in the basic model plus district income, fraction white, fraction female, fraction college graduates, state religion dummies and fraction of state population who believe abortion should always be legal, women and men equal, federal crime spending should be increased, government should spend more on social services and that there should be laws to protect homosexuals from discrimination. The NES did not ask the crime spending nor the homosexual discrimination question during the time of the election for the $106^{\text {th }}$ congress; I have substituted responses from the time of the election of the $105^{\text {th }}$ congress. The NES did not ask any of opinion questions during the time of the election for the $108^{\text {th }}$ congress; I have substituted responses from the time of the election for the $107^{\text {th }}$.

${ }^{1}$ Sample size [in brackets] varies due to availability of opinion questions in NES. 
FIgURE 1: MEAN NOW SCORE, By NuMBER OF FEMALE CHILDREN, $105^{\mathrm{TH}}$ CONGRESS

Representatives with Two Children

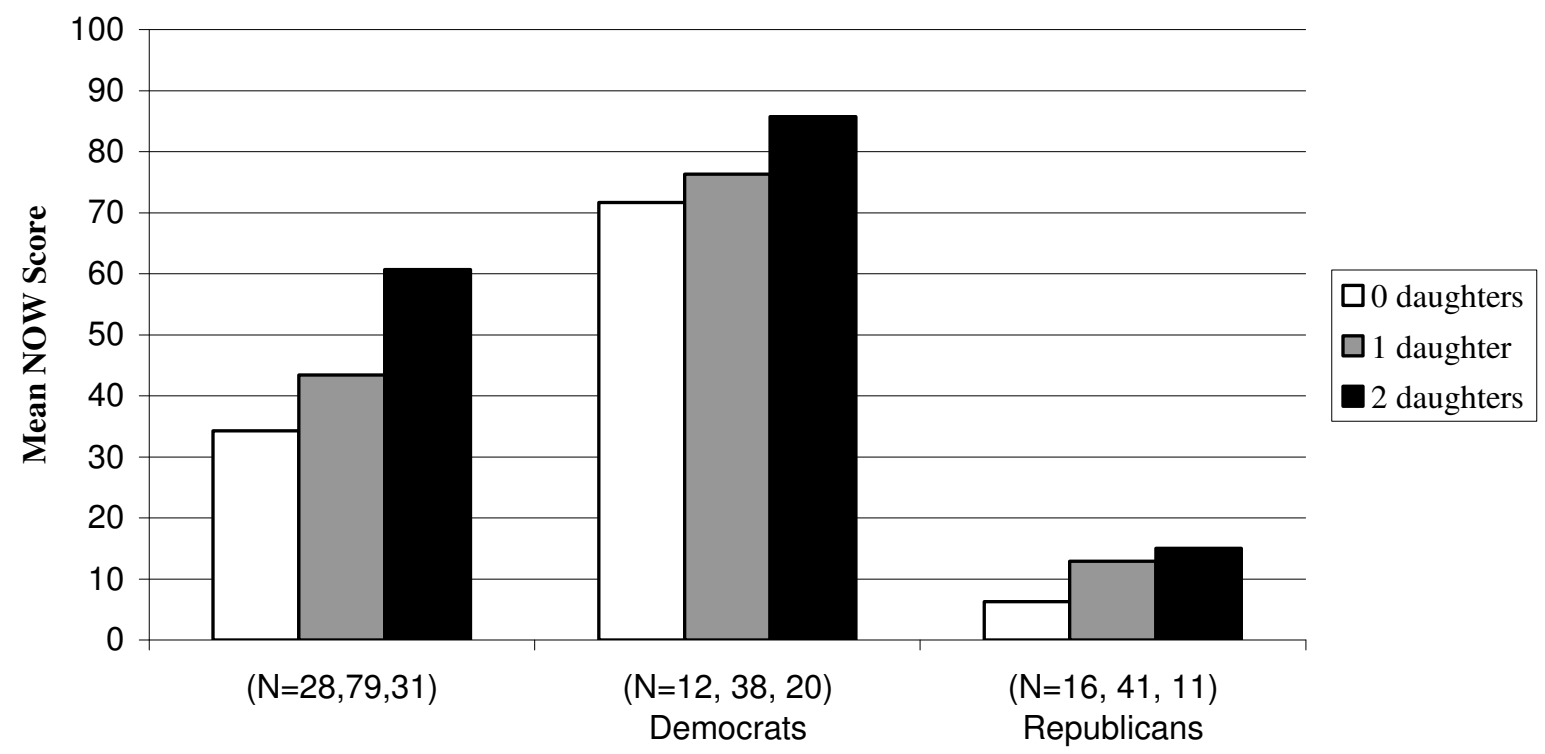

Representatives with Three Children

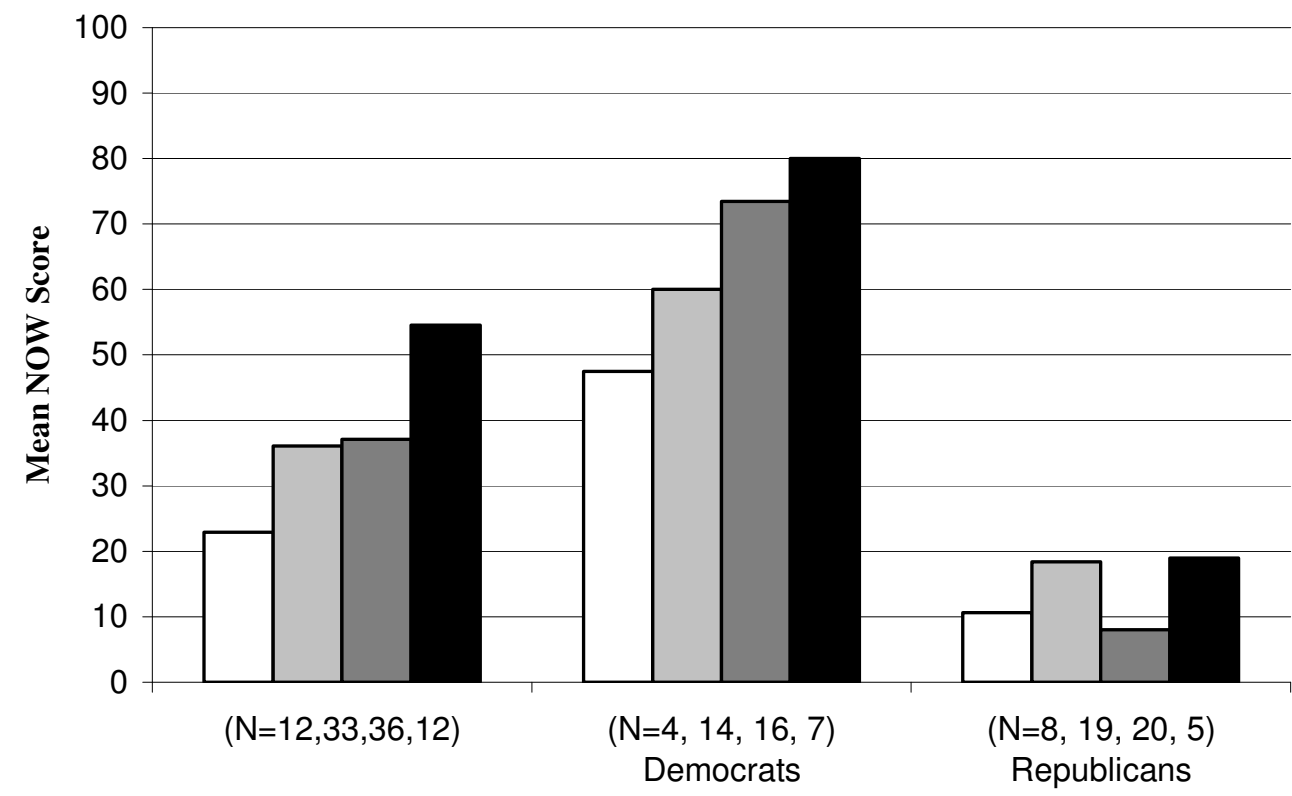

$\square 0$ daughters $\square 1$ daughter $\square 2$ daughters 3 daughters 

requirement. Never voted on. (Sponsorship $=+)^{1}$

Pay Equity: Two bills never voted on. The first amends the Fair Labor Standards Act of 1938 to prohibit discrimination (sex, race, national origin) in wages in comparable jobs within a workplace. The second provides additional remedies for women who are not paid equal wages for equal work. (Sponsorship $=+$ )

\section{Reproductive rights}

Abortion Ban: Overrides Clinton's veto of "partial-birth" abortion ban. (N=+)

Teen Access to Abortion: Makes it a federal crime to transport or accompany a minor across state lines for an abortion without parental notification. $(\mathrm{N}=+)$

Contraceptives for Federal Employees: Requires FEHBP plans to treat five contraceptives with parity with other prescription drugs. ( $\mathrm{Y}=+$ )

RU-486: Withholds funds from the FDA to review and approve drugs that induce medical abortions. $(\mathrm{N}=+)$

Teen Access to Contraceptives: Requires teens seeking prescription contraception at Title $\mathrm{X}$ clinics to have parental consent. $(\mathrm{N}=+)$

International Family Planning: Denies funding for family planning and population assistance to foreign organizations that perform or promote abortions. $(\mathrm{N}=+)$

Contraceptive Use: Defines certain contraceptives as abortifacients, thus prohibiting their use under FEHBP plans. ( $\mathrm{N}=+)$

\section{$\underline{\text { Safety }}$}

Violence Against Women: Addresses problems of domestic violence, rape and sexual assault through community based programs. Never voted on. (Sponsorship=+)

Hate Crimes: Permits federal prosecution of violent bias crimes based on sex, sexual orientation and disability. Never voted on. (Sponsorship $=+$ )

Note: Continued on next page. 
Appendix TABle 1 (CONTINUEd): Description of NOW House Votes

\begin{tabular}{rr}
\hline Description of Bill & Percent \\
& Voting \\
& with NOW \\
\hline
\end{tabular}

Economic Security

Affirmative Action in Federal Contracts: Repeals affirmative action programs in awarding federal transportation contracts.

$(\mathrm{N}=+)$

Working Families Flexibility: Gives employers more discretion as to when to provide comp time instead of paid overtime to

employees. $(\mathrm{N}=+)$

Bankruptcy: Treats credit card debt and child support/alimony in a similar manner when a debtor files for bankruptcy. (N=+)

Education

Private and Religious Schools: Provides federal monies for a voucher program. $(\mathrm{N}=+)$

Affirmative Action in Higher Education: Prohibits affirmative action for women and minorities in admission. $(\mathrm{N}=+)$

Education IRA: Allows individuals to use IRA's for elementary and secondary school. ( $\mathrm{N}=+$ )

Lesbian Rights

Discrimination in Federal Employment: Overturns Clinton's Executive Order banning discrimination based on sexual orientation. $(\mathrm{N}=+)$

Equal Health Care Benefits: Prohibits federal funds from being distributed to a locality that mandates that its contractors provide health care benefits to unmarked domestic partners of employees. $(\mathrm{N}=+)$

\section{$\underline{\text { Health }}$}

Patient's Rights: Provides patient protections under HMO's. Doesn't allow for individuals to sue health plans for personal injury

'Y/N/Sponsorship=+ indicates on what basis a legislator was awarded points by NOW with regards to the piece of legislation. "Y"/"N" indicates a

vote in favor/against. In some cases in which legislation never came to the floor for a vote, NOW awarded points for bill sponsorship. 
APPENDIX TABLE 2: EVIDENCE OF LEGISLATOR SELECTION For PROPORTION GIRLS, $105^{\mathrm{TH}}$ CONGRESS (DEPENDENT VARIABLE: PROPORTION DAUGHTERS)

\begin{tabular}{|c|c|c|c|}
\hline & (1) & (2) & (3) \\
\hline \multicolumn{4}{|l|}{ District Characteristics } \\
\hline Clinton vote share & $\begin{array}{l}.05 \\
(.14)\end{array}$ & $\begin{array}{l}.13 \\
(.25)\end{array}$ & $\begin{array}{l}.2 \\
(.26)\end{array}$ \\
\hline Median income (1000\$) & & $\begin{array}{l}.01 \\
(.00)\end{array}$ & $\begin{array}{l}.00 \\
(.00)\end{array}$ \\
\hline Fraction white & & $\begin{array}{l}-.07 \\
(.17)\end{array}$ & $\begin{array}{l}.08 \\
(.19)\end{array}$ \\
\hline Fraction female & & $\begin{array}{l}-1.05 \\
(1.53)\end{array}$ & $\begin{array}{l}-1.72 \\
(1.58)\end{array}$ \\
\hline Fraction college graduates & & $\begin{array}{l}-.59 \\
(.39)\end{array}$ & $\begin{array}{l}-.32 \\
(.4)\end{array}$ \\
\hline Constituent religion variables & & $\sqrt{ }$ & $\sqrt{ }$ \\
\hline \multicolumn{4}{|l|}{ District Opinions } \\
\hline $\begin{array}{l}\text { Fraction of state population who believe } \ldots \\
\text { Abortion should always be legal }\end{array}$ & & & $\begin{array}{l}.25 \\
(.29)\end{array}$ \\
\hline Women are equal to men & & & $\begin{array}{l}.82 \\
(.52)\end{array}$ \\
\hline Federal crime spending should be increased & & & $\begin{array}{c}-1.53 * * \\
(.47)\end{array}$ \\
\hline Government should spend more on services (health, education) & & & $\begin{array}{l}-.06 \\
(.36)\end{array}$ \\
\hline There should be laws to protect homosexuals from discrimination & & & $\begin{array}{l}.07 \\
(.29)\end{array}$ \\
\hline $\mathrm{N}$ & 374 & 372 & 333 \\
\hline
\end{tabular}

